\title{
Three New Indole Alkaloids from Tabernaemontana divaricata
}

\author{
Yan Deng ${ }^{1,2,3} \cdot$ Mei-Fen Bao ${ }^{1,3} \cdot$ Bao-Bao Shi ${ }^{1,2,3} \cdot$ Jing $\mathrm{Wu}^{1,3} \cdot \mathrm{Xiann}$-Hai Cai ${ }^{1,3}$ (D)
}

Received: 8 March 2018 / Accepted: 3 May 2018/ Published online: 12 May 2018

(C) The Author(s) 2018

\section{Abstract}

Three new monoterpene indole alkaloids, $3 \alpha$-hydroxymethyl-ibogamine (1), 3 $\alpha$-acetatemethoxyl-ibogamine (2), 16 $\alpha$-hydroxyl-ibogamine (3) together with six known alkaloids were isolated from the branches and leaves of Tabernaemontana divaricata (Apocynaceae). The structures of these alkaloids were determined by spectroscopic analyses. All isolated compounds showed no significant cytotoxicity against SGC-7901 gastric cancer, HeLa, and A-549 lung cancer cell lines $\left(\mathrm{IC}_{50}>20 \mu \mathrm{M}\right)$.

\section{Graphical Abstract}
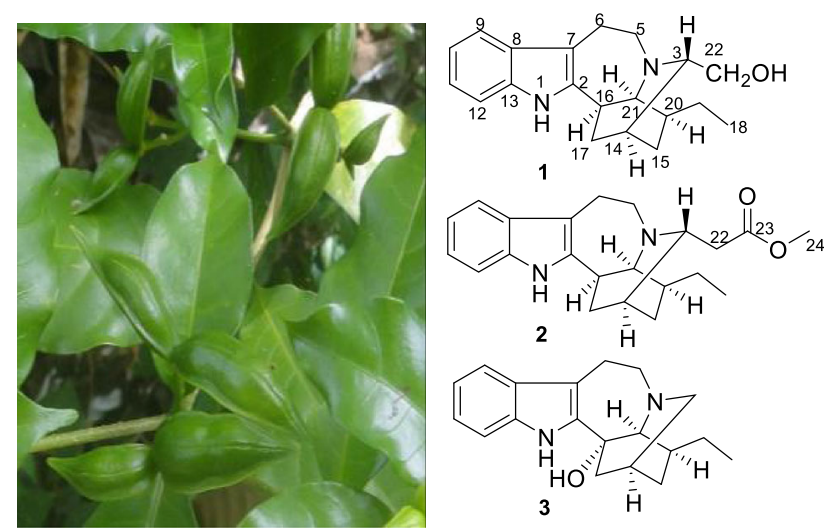

Keywords Tabernaemontana divaricata $\cdot$ Monoterpene indole alkaloids $\cdot 3 \alpha$-hydroxymethyl-ibogamine $\cdot 3 \alpha-$ acetatemethoxyl-ibogamine $\cdot 16 \alpha$-hydroxyl-ibogamine $\cdot$ Apocynaceae

Electronic supplementary material The online version of this article (https://doi.org/10.1007/s13659-018-0166-x) contains supplementary material, which is available to authorized users.

Xiang-Hai Cai

xhcai@mail.kib.ac.cn

1 State Key Laboratory of Phytochemistry and Plant Resources in West China, Kunming Institute of Botany, Chinese Academy of Sciences, Kunming 650201, People's Republic of China

2 University of Chinese Academy of Sciences, Beijing 100049, People's Republic of China

3 Yunnan Key Laboratory of Natural Medicinal Chemistry, Kunming 650201, People's Republic of China

\section{Introduction}

Alkaloids are unique natural products denoted by the presence of a nitrogen atom as part of a heterocyclic ring, constituting a highly diverse group of compounds. At present, more than 12,000 different alkaloids, all of them plant-derived, are known. To deal with this enormous diversity, these compounds are organized into dozens of structural related groups [1, 2]. Among this class of compounds, monoterpene indole alkaloids (MIAs) may account for a quarter of naturally occurring alkaloids. Both, their highly intricate chemical structures and pronounced pharmacological activities attracted many people from the research community to illuminate the structural diversity, 
bioactivities and biosynthetic pathways [3]. Species of the genus Tabernaemontana L. (Apocynaceae) are widely distributed in tropical and subtropical regions of Africa, Asia, North America, Pacific Islands, South America, including five species in China. This species are recognized as a rich source of MIAs [4], whereas the Iboga-type alkaloids ibogamine [5], voacangine [6], and coronaridine [7] are common in these species, hence, they can be regarded as chemical markers for the genus. These compounds feature a nitrogen-containing seven-membered ring which is linked to the indole system. As part of continuing search for bioactive alkaloids, three new alkaloids named as $3 \alpha$-hydroxymethyl-ibogamine (1), $3 \alpha$-acetatemethoxylibogamine (2), 16 $\alpha$-hydroxyl-ibogamine (3), as well as six known alkaloids 4-9, were isolated from the branches and leaves of $T$. divaricata (L.) R. Br. ex Roem. \& Schult. The known alkaloids were identified as coronaridine (4) [8], isovoacangine (5) [9], taberdivarine $\mathrm{G}$ (6) [10], voacangine (7) [11], heyneanine (8) [12], coronaridine hydroxyindolenine (9) [13]. All of them belong to the iboga-type alkaloids. In the assessment of their bioactivities, the isolated alkaloids did not show significant activities against SGC-7901 gastric cancer, HeLa, and A-549 lung cancer cell lines $\left(\mathrm{IC}_{50}>20 \mu \mathrm{M}\right)$.

\section{Results and discussion}

The alkaloid fraction of $T$. divaricata was separated as described in experimental section to yield a total of nine compounds, including three new alkaloids 1-3 (Fig. 1). All compounds showed a positive response to Dragendorff's reagent on TLC.

Compound 1 was obtained as pale yellow amorphous powder. The UV absorption bands at 284, 227, and $214 \mathrm{~nm}$ suggest the presence of an indole chromophore [14]. The molecular formula of compound $\mathbf{1}$ was established as $\mathrm{C}_{20} \mathrm{H}_{26} \mathrm{~N}_{2} \mathrm{O}$ with nine degrees of unsaturation by
HRESIMS $\left([\mathrm{M}+\mathrm{H}]^{+}\right.$at $m / z$ 311.2118). The ${ }^{1} \mathrm{H}$ NMR data (Table 1) indicated an unsubstituted indole ring with signals at $\delta_{\mathrm{H}} 7.38(1 \mathrm{H}, \mathrm{d}, J=7.7 \mathrm{~Hz}), 6.94(1 \mathrm{H}, \mathrm{t}, J=7.7 \mathrm{~Hz})$, $6.99(1 \mathrm{H}, \mathrm{t}, J=7.7 \mathrm{~Hz}), 7.22(1 \mathrm{H}, \mathrm{d}, J=7.7 \mathrm{~Hz})$, and one methyl signal at $\delta_{\mathrm{H}} 0.87(3 \mathrm{H}, \mathrm{t}, J=7.3 \mathrm{~Hz})$. The ${ }^{13} \mathrm{C} \mathrm{NMR}$ and DEPT data (Table 1) revealed the presence of four quaternary carbons $\left(\delta_{\mathrm{C}} 143.1,136.2,130.7,108.6\right)$, nine methines $\left(\delta_{\mathrm{C}} 121.1,119.1,118.3,111.0,59.8,59.7,42.3\right.$, $41.9,27.9)$, six methylenes $\left(\delta_{\mathrm{C}} 62.4,53.8,37.2,27.9,27.4\right.$, $21.3)$, and one methyl group $\left(\delta_{\mathrm{C}} 12.2\right)$. The $1 \mathrm{D}$ NMR spectroscopic data of $\mathbf{1}$ were similar to those of ibogamine, except the presence of a hydroxymethyl group at C-3 and a methine carbon $\left(\delta_{\mathrm{C}} 59.8\right)$ of C-3 in $\mathbf{1}$ instead of a methylene $\left(\delta_{\mathrm{C}} 49.9\right)$ in ibogamine [5]. The HMBC correlations from $\delta_{\mathrm{H}} 3.20(\mathrm{H}-3)$ to $\delta_{\mathrm{C}} 27.4(\mathrm{C}-15), \delta_{\mathrm{C}} 37.2(\mathrm{C}-17), \delta_{\mathrm{C}}$ $53.8(\mathrm{C}-5)$, and from $\delta_{\mathrm{H}} 3.48(\mathrm{H}-22)$ to $\delta_{\mathrm{C}} 27.9(\mathrm{C}-14), \delta_{\mathrm{C}}$ 59.8 (C-3) confirmed this result (Fig. 2). Thus, the planar structure of compound $\mathbf{1}$ was determined. The relative configuration of $\mathbf{1}$ was determined on the basis of the ROESY spectrum, the correlation of $\mathrm{H}-17\left(\delta_{\mathrm{H}} 2.17\right) / \mathrm{H}-16$, H-3/H-17 ( $\left.\delta_{\mathrm{H}} 1.61\right)$, suggested H-3 was $\beta$-oriented (Fig. 3). Consequently, the structure of $\mathbf{1}$ was confirmed as shown in Fig. 1, and named $3 \alpha$-hydroxymethyl-ibogamine (1).

Compound $\mathbf{2}$ was isolated as pale yellow amorphous powder. The ${ }^{1} \mathrm{H}$ and ${ }^{13} \mathrm{C}$ NMR data (Table 1 ) of $\mathbf{2}$ was very similar to those of $\mathbf{1}$, except the presence of an additional $\mathrm{COOCH}_{3}$ signal $\left(\delta_{\mathrm{H}} 3.60, \delta_{\mathrm{C}} 51.5, \delta_{\mathrm{C}} 173.2\right)$ and the ${ }^{13} \mathrm{C}$ NMR chemical shift at C-22 $\left(\delta_{\mathrm{C}} 38.5\right)$ was different from that in compound $1\left(\delta_{\mathrm{C}} 62.4\right)$. Moreover, compound 2 was assigned the molecular formula of $\mathrm{C}_{22} \mathrm{H}_{28} \mathrm{~N}_{2} \mathrm{O}_{2}$, differing from 1 by addition of 42 daltons (da) and consistent with substitution of an $\mathrm{OH}$ by a $\mathrm{COOCH}_{3}$ group based on the analysis of HRESIMS $\left([\mathrm{M}+\mathrm{H}]^{+}\right.$at $m / z$ 353.2223). This assumption was supported by $\mathrm{HMBC}$ correlations from $\delta_{\mathrm{H}}$ $2.39(\mathrm{H}-22)$ to $\delta_{\mathrm{C}} 30.7(\mathrm{C}-14), \delta_{\mathrm{C}} 55.4(\mathrm{C}-3), \delta_{\mathrm{C}} 173.2(\mathrm{C}-$ 23), and from $\delta_{\mathrm{H}} 3.60(\mathrm{H}-24)$ to $\delta_{\mathrm{C}} 173.2$ (C-23) (Fig. 2). Similar to 1, the ROESY correlation of H-17 $\left(\delta_{\mathrm{H}} 2.15\right) / \mathrm{H}-$ $16, \mathrm{H}-3 / \mathrm{H}-17\left(\delta_{\mathrm{H}} 1.59\right), \mathrm{H}-15\left(\delta_{\mathrm{H}} 1.34\right) / \mathrm{H}-22\left(\delta_{\mathrm{H}} 2.39\right)$
Fig. 1 Structures of compounds 1-9
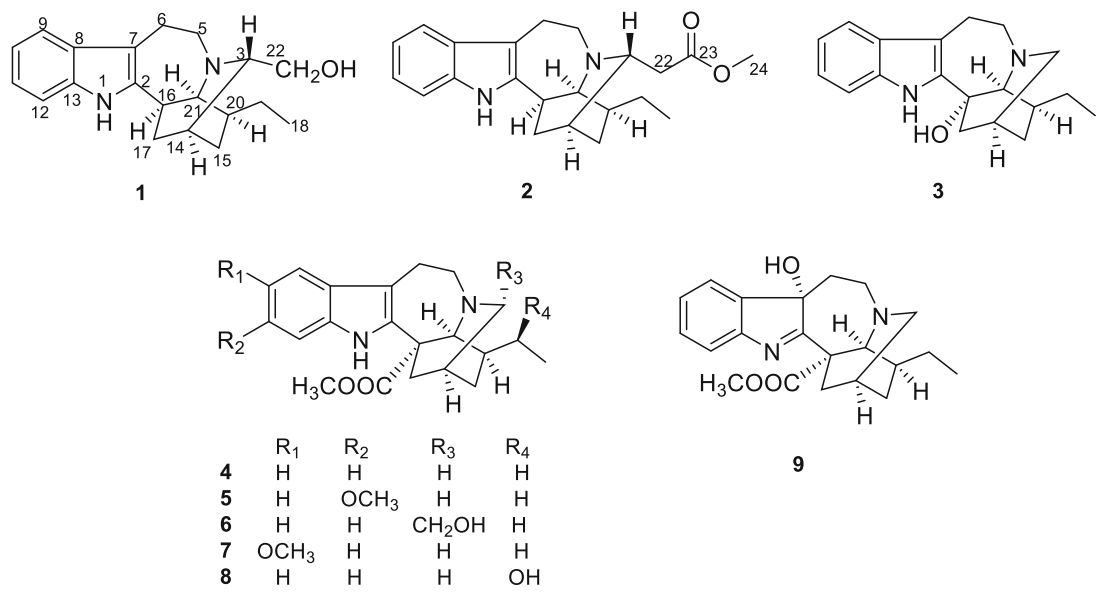

9 
Table $1{ }^{1} \mathrm{H}(400 \mathrm{MHz})$ and ${ }^{13} \mathrm{C}(125 \mathrm{MHz})$ NMR data for compounds $\mathbf{1}-\mathbf{3}(\delta \text { in ppm, } J \text { in } \mathrm{Hz})^{\mathrm{a}}$

\begin{tabular}{|c|c|c|c|c|c|c|}
\hline \multirow[t]{2}{*}{ No. } & \multicolumn{2}{|l|}{1} & \multicolumn{2}{|l|}{2} & \multicolumn{2}{|l|}{3} \\
\hline & $\delta_{\mathrm{C}}$ & $\delta_{\mathrm{H}}$ & $\delta_{\mathrm{C}}$ & $\delta_{\mathrm{H}}$ & $\delta_{\mathrm{C}}$ & $\delta_{\mathrm{H}}$ \\
\hline 1 & - & $9.70, \mathrm{~s}$ & - & $9.70, \mathrm{~s}$ & - & $9.74, \mathrm{~s}$ \\
\hline 2 & $143.1 \mathrm{~s}$ & - & $142.9 \mathrm{~s}$ & - & $145.6 \mathrm{~s}$ & - \\
\hline 3 & $59.8 \mathrm{~d}$ & $3.20, \mathrm{dd}(8.8,4.1)$ & $55.4 \mathrm{~d}$ & $3.56, \mathrm{~m}$ & $49.8 \mathrm{t}$ & 2.89 , overlapped \\
\hline 5 & $53.8 \mathrm{t}$ & $\begin{array}{l}3.00, \mathrm{~m} \\
3.53 \text {, ddd }(14.4,4.8,2.2)\end{array}$ & $53.0 \mathrm{t}$ & $\begin{array}{l}2.99, \mathrm{~m} \\
3.46, \mathrm{ddd}(14.4,4.8,2.1)\end{array}$ & $54.4 \mathrm{t}$ & $\begin{array}{l}3.12, \text { ddd }(12.5,11.0,4.2) \\
3.27, \mathrm{~m}\end{array}$ \\
\hline 6 & $21.3 \mathrm{t}$ & $\begin{array}{l}2.63 \text {, ddd }(16.4,4.0,2.2) \\
3.37, \mathrm{~m}\end{array}$ & $21.4 \mathrm{t}$ & $\begin{array}{l}2.63, \mathrm{~m} \\
3.35, \mathrm{ddd}(17.1,12.7,4.8)\end{array}$ & $22.1 \mathrm{t}$ & $\begin{array}{l}2.64, \mathrm{~m} \\
3.33, \mathrm{~m}\end{array}$ \\
\hline 7 & $108.6 \mathrm{~s}$ & - & $108.5 \mathrm{~s}$ & - & $106.5 \mathrm{~s}$ & - \\
\hline 8 & $130.7 \mathrm{~s}$ & - & $130.7 \mathrm{~s}$ & - & $130.2 \mathrm{~s}$ & - \\
\hline 9 & $118.3 \mathrm{~d}$ & $7.38, \mathrm{~d}(7.7)$ & $118.4 \mathrm{~d}$ & $7.39, \mathrm{~d}(7.7)$ & $118.8 \mathrm{~d}$ & $7.38, \mathrm{~d}(7.7)$ \\
\hline 10 & $119.1 \mathrm{~d}$ & $6.94, \mathrm{t}(7.7)$ & $119.1 \mathrm{~d}$ & $6.95, \mathrm{t}(7.7)$ & $119.0 \mathrm{~d}$ & $6.95, \mathrm{t}(7.7)$ \\
\hline 11 & $121.1 \mathrm{~d}$ & $6.99, \mathrm{t}(7.7)$ & $121.2 \mathrm{~d}$ & $7.00, \mathrm{t}(7.7)$ & $121.3 \mathrm{~d}$ & $7.01, \mathrm{t}(7.7)$ \\
\hline 12 & $111.0 \mathrm{~d}$ & $7.22, \mathrm{~d}(7.7)$ & $111.0 \mathrm{~d}$ & $7.23, \mathrm{~d}(7.7)$ & $111.5 \mathrm{~d}$ & $7.36, \mathrm{~d}(7.7)$ \\
\hline 13 & $136.2 \mathrm{~s}$ & - & $136.2 \mathrm{~s}$ & - & $135.4 \mathrm{~s}$ & - \\
\hline 14 & $27.9 \mathrm{~d}$ & $1.96, \mathrm{~m}$ & $30.7 \mathrm{~d}$ & $1.70, \mathrm{~m}$ & $28.9 \mathrm{~d}$ & 1.87 , overlapped \\
\hline 15 & $27.4 \mathrm{t}$ & $\begin{array}{l}1.40, \text { overlapped } \\
1.59, \text { overlapped }\end{array}$ & $27.4 \mathrm{t}$ & $\begin{array}{l}1.34, \mathrm{~m} \\
1.63, \mathrm{~m}\end{array}$ & $32.6 \mathrm{t}$ & $\begin{array}{l}1.05, \mathrm{~m} \\
1.83, \text { overlapped }\end{array}$ \\
\hline 16 & $41.9 \mathrm{~d}$ & 3.11 , ddd $(11.7,3.9,2.0)$ & $41.5 \mathrm{~d}$ & 3.11 , ddd $(11.7,3.7,2.0)$ & $74.7 \mathrm{~s}$ & - \\
\hline 17 & $37.2 \mathrm{t}$ & $\begin{array}{l}\text { 1.61, overlapped } \\
2.17, \mathrm{~m}\end{array}$ & $36.9 \mathrm{t}$ & $\begin{array}{l}1.59, \mathrm{~m} \\
2.15, \mathrm{~m}\end{array}$ & $44.0 \mathrm{t}$ & $\begin{array}{l}1.84, \text { overlapped } \\
1.93, \text { overlapped }\end{array}$ \\
\hline 18 & $12.2 \mathrm{q}$ & $0.87, \mathrm{t}(7.3)$ & $12.2 \mathrm{q}$ & $0.89, \mathrm{t}(7.3)$ & $12.1 \mathrm{q}$ & $0.87, \mathrm{t}(7.4)$ \\
\hline 19 & $27.9 \mathrm{t}$ & 1.48 , overlapped & $28.1 \mathrm{t}$ & $1.45, \mathrm{~m}$ & $28.1 \mathrm{t}$ & $1.49, \mathrm{~m}$ \\
\hline 20 & $42.3 \mathrm{~d}$ & $1.50, \mathrm{~m}$ & $42.2 \mathrm{~d}$ & $1.52, \mathrm{~m}$ & $35.1 \mathrm{~d}$ & $2.27, \mathrm{~m}$ \\
\hline 21 & $59.7 \mathrm{~d}$ & 2.85 , overlapped & $59.8 \mathrm{~d}$ & $2.85, \mathrm{~s}$ & $63.4 \mathrm{~d}$ & $2.79, \mathrm{~d}(1.8)$ \\
\hline 22 & $62.4 \mathrm{t}$ & $\begin{array}{l}3.48, \text { dd }(10.7,8.8) \\
3.61, \text { dd }(10.7,4.1)\end{array}$ & $38.5 \mathrm{t}$ & $\begin{array}{l}2.39, \mathrm{dd}(14.8,8.4) \\
2.60, \mathrm{~d}(5.0)\end{array}$ & - & - \\
\hline 23 & - & - & $173.2 \mathrm{~s}$ & - & - & - \\
\hline 24 & - & - & $51.5 \mathrm{q}$ & $3.60, \mathrm{~s}$ & - & - \\
\hline
\end{tabular}

${ }^{\mathrm{a}}$ Data $(\delta)$ were measured in acetone- $d_{6}$

Fig. 2 Key HMBC correlations of compounds 1-3
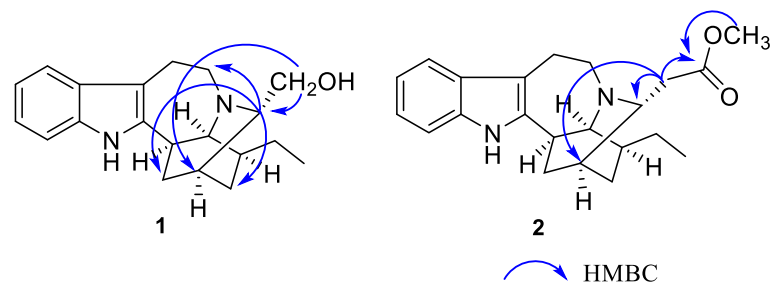

suggested that H-3 was $\beta$-oriented (Fig. 3). Hence, compound 2 was identified as $3 \alpha$-acetatemethoxyl-ibogamine (2).

Compound 3 showed a molecular ion peak at $\mathrm{m} / \mathrm{z}$ 297.1964 $[\mathrm{M}+\mathrm{H}]^{+}$(calcd. 297.1961) by HRESIMS, corresponding to the molecular formula $\mathrm{C}_{19} \mathrm{H}_{24} \mathrm{~N}_{2} \mathrm{O}$, which is 16 da more than that of the known alkaloid ibogamine [5]. Comparison of its 1D NMR data (Table 1) with those of ibogamine showed that the major differences were the signal due to C-17, C-21 were found to resonate at lower field $\left(\delta_{\mathrm{C}} 44.0,63.4\right)$ and a quaternary carbon $\left(\delta_{\mathrm{C}} 74.7\right)$ in 3 substituted a methine in ibogamine. In addition, the HMBC correlations from the cross peaks of $\mathrm{H}-17\left(\delta_{\mathrm{H}} 1.93\right) / \mathrm{C}-16$ $\left(\delta_{\mathrm{C}} 74.7\right), \mathrm{C}-2\left(\delta_{\mathrm{C}} 145.6\right)$, and of $\mathrm{H}-21\left(\delta_{\mathrm{H}} 2.79\right) / \mathrm{C}-20\left(\delta_{\mathrm{C}}\right.$ $35.1), \mathrm{C}-17\left(\delta_{\mathrm{C}} 44.0\right), \mathrm{C}-5\left(\delta_{\mathrm{C}} 54.4\right), \mathrm{C}-16\left(\delta_{\mathrm{C}} 74.7\right), \mathrm{C}-2$ $\left(\delta_{\mathrm{C}} 145.6\right)$ located the quaternary carbon of C-16 (Fig. 2), 


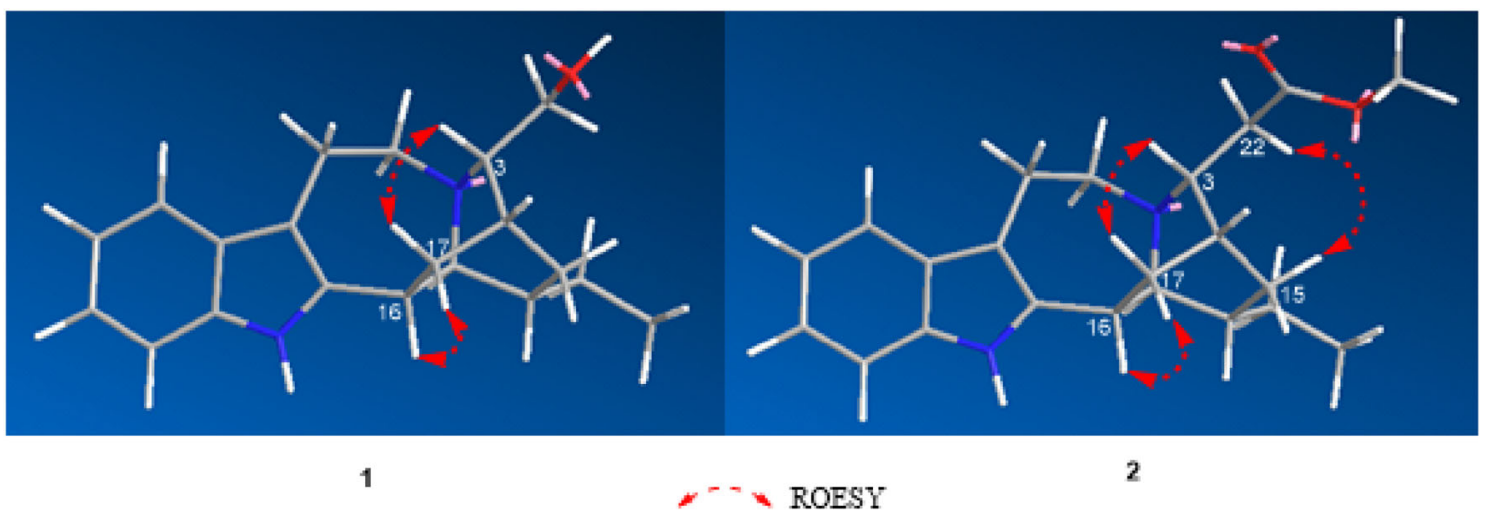

Fig. 3 Key ROESY correlations of compounds $\mathbf{1}$ and $\mathbf{2}$

indicating that 3 was 16-hydroxy ibogamine. According to the biogenetic pathway of iboga-type monoterpenoid indole alkaloids and molecular model, the substituent of C-16 was $\alpha$-oriented. Therefore, the structure of $3,16 \alpha$ hydroxyl-ibogamine (3), was defined as shown in Fig. 2.

Compounds 1-9 were evaluated for their cytotoxicity activity based on the MTT method (camptothecin was used as a positive control). However, none of these compounds showed any significant activity against SGC-7901 gastric cancer, HeLa, and A-549 lung cancer cell lines $\left(\mathrm{IC}_{50}>20 \mu \mathrm{M}\right)$.

\section{Experimental}

\subsection{General Experimental Procedures}

Optical rotations were measured with a JASCO P-1020 digital polari-meter (Horiba, Kyoto, Japan). UV spectra were recorded on a Shimadzu UV2401PC spectrometer (Shimadzu, Kyoto, Japan). NMR spectra were performed on a Bruker AVANCE III $400 \mathrm{MHz}$ spectrometers (Bruker Biospin GmbH, Karlsruhe, Germany) and a Bruker AVANCE III $500 \mathrm{MHz}$ spectrometers (Bruker Biospin GmbH, Karlsruhe, Germany). HRESIMS data were acquired on a Shimadzu UPLC-IT-TOF spectrometer (Shimadzu, Kyoto, Japan). HPLC analyses were performed on a Waters instrument consisting of a Waters 1525EF pump coupled with a Waters 2998 photodiode array detector and a Waters fraction collector III. The analytical separations were performed on a Sunfire $\mathrm{C}_{18}$ column $(5 \mu \mathrm{m}, 150 \mathrm{~mm} \times 4.6 \mathrm{~mm})$. Preparative separations were done a Sunfire $\mathrm{C}_{18}$ column $(5 \mu \mathrm{m}, 250 \mathrm{~mm} \times 19 \mathrm{~mm})$. The following stationary phases were used for column chromatography (CC): silica gel (200-300 mesh, Qingdao Marine Chemical Ltd., Qingdao, China), $\mathrm{C}_{18}$ silica gel (50 $\mu \mathrm{m}$, YMC Co. Ltd., Japan), and Sephadex LH-20 (Mitsubishi Co., Ltd., Japan). Each separation step was monitored by TLC on silica gel plates (GF254, Qingdao Marine Chemical Co., Ltd., Qingdao, China), and spots were visualized using Dragendorff's reagent. MPLC was performed using a Buchi pump system coupled with RP-18 silica gel-packed glass columns $(15 \times 230$ and $26 \times 460 \mathrm{~mm}$, respectively).

\subsection{Plant Material}

Leaves and branches of Tabernaemontana divaricata were collected in Hainan Province, P. R. China, and identified by Dr. Sheng-Zhou Huang. A voucher specimen (Cai20150424) was deposited in the State Key Laboratory of Phytochemistry and Plant Resources in West China, Kunming Institute of Botany, Chinese Academy of Sciences.

\subsection{Extraction and Isolation}

Air-dried branches and leaves of $T$. divaricata (46 kg) were powdered and extracted with $\mathrm{MeOH}(96 \mathrm{~h} \times 3)$ at room temperature. The extract $(2.5 \mathrm{~kg})$ was partitioned between $0.5 \% \mathrm{HCl}$ solution and EtOAc, and the acidic water layer was adjusted to $\mathrm{pH} 8-9$ with $15 \%$ ammonia solution and subsequently extracted with EtOAc. This yielded $325 \mathrm{~g}$ crude alkaloid extract. This extract was subjected to column chromatography (CC) over silica gel and eluted with gradient $\mathrm{CHCl}_{3}-\mathrm{Me}_{2} \mathrm{CO}(1: 0-1: 1, \mathrm{v} / \mathrm{v})$ to afford five fractions (I-V).

Fraction II (20.3 g) was further chromatographed on a $\mathrm{C}_{18}$ MPLC column eluted with a gradient of $\mathrm{MeOH}-\mathrm{H}_{2} \mathrm{O}$ (30:70-100:0, v/v). Six subfractions II-1 to II-6 were collected from this procedure. Subfraction II-2 was subjected to $\mathrm{C}_{18}$ MPLC column once again using $\mathrm{MeOH}-\mathrm{H}_{2} \mathrm{O}$ (20:80-70:30, v/v) as eluent which yielded seven subfractions (II-2-1 to II-2-7). Subfraction II-2-5 was refined by a preparative $\mathrm{C}_{18}$ HPLC column using a gradient of MeCN$\mathrm{H}_{2} \mathrm{O}$ (45:55-60:40, v/v). This afforded $4.0 \mathrm{mg}$ of 1 . 
Fraction II-2-7 was further purified by preparative HPLC with a gradient from 50 to $65 \%$ aqueous acetonitrile. This afforded $6.7 \mathrm{mg}$ of $\mathbf{8}$. Fraction II-3 was separated by reversed phase MPLC column with a gradient of $\mathrm{MeOH}-$ $\mathrm{H}_{2} \mathrm{O}$ (40:60-85:15, v/v). This step afforded five subfractions (II-3-1 to II-3-5). Fraction II-3-5 was separated by prep. HPLC with a gradient of $\mathrm{MeOH}-\mathrm{H}_{2} \mathrm{O}$ (65:35-80:20, $\mathrm{v} / \mathrm{v})$. This step yielded $8.2 \mathrm{mg}$ of compound 9. Fraction II-4 was separated using a Sephadex LH-20 column eluted with $\mathrm{MeOH}$. Four subfractions (II-4-1 to II-4-4) were collected. Fraction II-4-2 was separated on a prep. $\mathrm{C}_{18}$ HPLC using a gradient of $\mathrm{MeCN}-\mathrm{H}_{2} \mathrm{O}(55: 45-70: 30, \mathrm{v} / \mathrm{v})$ which afforded $6.7 \mathrm{mg}$ of 6. Fraction II-4-3 was subjected to a prep. $\mathrm{C}_{18}$ HPLC eluted with a gradient of $\mathrm{MeOH}-\mathrm{H}_{2} \mathrm{O}$ (75:25-90:10, $\mathrm{v} / \mathrm{v})$. This step generated $2.2 \mathrm{mg}$ of $\mathbf{4}$. Compound 7 (1.5 g) was crystalized from fraction II-5. Subfraction II-6 was subjected to $\mathrm{C}_{18}$ MPLC eluted with mixtures of $\mathrm{MeOH}$ and water (60:40-90:10, v/v). Five subfractions (II-6-1 to II-65) were collected. Fraction II-6-2 was further separated using reversed phase MPLC with a gradient of $\mathrm{MeOH}$ (from 60 to $85 \%$ ) in $\mathrm{H}_{2} \mathrm{O}$, affording one subfraction (II-62-4). Refining of this subfraction by prep. HPLC with a gradient of $\mathrm{MeCN}-\mathrm{H}_{2} \mathrm{O}(65: 35-80: 20, \mathrm{v} / \mathrm{v})$ gave $30.9 \mathrm{mg}$ of 5. Fraction II-6-5 was chromatographed over Sephadex LH-20 column eluted with $\mathrm{MeOH}$. This generated five subfractions (II-6-5-1 to II-6-5-5). Fraction II-6-5-1 was separated by prep. HPLC using a gradient of $\mathrm{H}_{2} \mathrm{O}$ (from 70 to $85 \%$ ) in $\mathrm{MeCN}$. This step yielded $7.1 \mathrm{mg}$ of 2 and $5.7 \mathrm{mg}$ of $\mathbf{3}$.

\subsection{1 $3 \alpha$-Hydroxymethyl-ibogamine (1)}

Pale yellow amorphous powder, $[\alpha]_{\mathrm{D}}^{17.5}-29.9$ (c 0.13 , $\mathrm{MeOH}) ; \mathrm{UV}(\mathrm{MeOH}) \lambda_{\max }(\log \varepsilon) 196$ (4.10), 214 (4.30), 227 (4.41), 284 (3.75) nm; ${ }^{1} \mathrm{H}$ and ${ }^{13} \mathrm{C}$ NMR data, see Table 1. HRESIMS $\mathrm{m} / \mathrm{z} 311.2118[\mathrm{M}+\mathrm{H}]^{+}$(calcd. for $\mathrm{C}_{20} \mathrm{H}_{26} \mathrm{~N}_{2} \mathrm{O}, 311.2118$ ).

\subsection{2 $3 \alpha$-acetatemethoxyl-ibogamine (2)}

Pale yellow amorphous powder, $[\alpha]_{\mathrm{D}}^{17.5}-15.0(c 0.11$, $\mathrm{MeOH}$ ); UV (MeOH) $\lambda_{\max }(\log \varepsilon) 211$ (4.26), 227 (4.40), 285 (3.74) nm; ${ }^{1} \mathrm{H}$ and ${ }^{13} \mathrm{C}$ NMR data, see Table 1. HRESIMS $\mathrm{m} / z \quad 353.2223[\mathrm{M}+\mathrm{H}]^{+}$(calcd. for $\left.\mathrm{C}_{22} \mathrm{H}_{28} \mathrm{~N}_{2} \mathrm{O}_{2}, 353.2224\right)$.

\subsubsection{6 -hydroxyl-ibogamine (3)}

Pale yellow amorphous powder, $[\alpha]_{\mathrm{D}}^{17.5}-19.2$ (c 0.07 , $\mathrm{MeOH}$ ); UV (MeOH) $\lambda_{\max }(\log \varepsilon) 211$ (4.09), 223 (4.10), 285 (3.49) nm; ${ }^{1} \mathrm{H}$ and ${ }^{13} \mathrm{C}$ NMR data, see Table 1. HRESIMS $m / z, 297.1964[\mathrm{M}+\mathrm{H}]^{+}$(calcd. for $\mathrm{C}_{19} \mathrm{H}_{24} \mathrm{~N}_{2} \mathrm{O}$, 297.1961).

\subsection{Cytotoxicity}

The human A-549 lung cancer, SGC-7901 gastric cancer, and HeLa cell lines were used in the performed cytotoxic assay. These cells were grown in DMEM media (HyClone, USA) supplemented with $10 \%$ fetal bovine serum (HyClone, USA) at $37{ }^{\circ} \mathrm{C}$ in $5 \% \mathrm{CO}_{2}$. The cytotoxicity of all alkaloids was determined based on the MTT method in 96-well microplates. In short, $100 \mu \mathrm{L}$ adherent cells were seeded into each well and incubated for $12 \mathrm{~h}$ before the addition of the test alkaloids/drug. At the same time, the suspended cells were seeded at an initial density of $1 \times 10^{5}$ cells $/ \mathrm{mL}$ just before addition of the purified compounds. Each tumor cell line was exposed to a single test compound at concentrations of $0.8,4$ and $20 \mu \mathrm{M}$ in DMSO. Camptothecin was used as positive control. Each test was performed in triplicate. After treatment, cell viability was assessed, cell growth graphed and $\mathrm{IC}_{50}$ values were calculated using Reed and Muench's method [15].

Acknowledgements This project was financially supported by the Applied Basic Research Programs of Yunnan Province (No. 2016FA030) and the National Natural Science Foundation of China (31370377). The authors are grateful to Dr. Sheng-Zhou Huang for identification of plant samples.

\section{Compliance with Ethical Standards}

Conflict of interest The authors declare no conflict of interest.

Open Access This article is distributed under the terms of the Creative Commons Attribution 4.0 International License (http://creative commons.org/licenses/by/4.0/), which permits unrestricted use, distribution, and reproduction in any medium, provided you give appropriate credit to the original author(s) and the source, provide a link to the Creative Commons license, and indicate if changes were made.

\section{References}

1. S.E. O'Connor, J.J. Maresh, Nat. Prod. Rep. 23, 532-547 (2006)

2. H. Abdelkafi, B. Nay, Nat. Prod. Rep. 29, 845-869 (2012)

3. K. Folkers, R.T. Major, J. Am. Chem. Soc. 59, 1580-1581 (1937)

4. Editorial Board of the Flora of China of Chinese Academy of Sciences, Flora of China, vol 16 (Science Press, Beijing, 1996), p. 153

5. M. Damak, C. Poupat, A. Ahon, Tetrahedron Lett. 39, 3531-3534 (1976)

6. D.W. Thomas, K. Biemann, Tetrahedron 24, 4223-4231 (1968)

7. M. Gorman, N. Neuss, N.J. Cone, J.A. Deyrup, J. Am. Chem. Soc. 82, 1142-1145 (1960)

8. P.S. Pereira, S.D.C. Franca, P.V.A.D. Oliveira, C.M.D.S. Breves, S.I.V. Pereira, Quim. Nova 31, 20-24 (2008)

9. J.P. Kutney, A. Horinaka, R.S. Ward, B.R. Worth, Can. J. Chem. 58, 1829-1838 (1980)

10. B.J. Zhang, X.F. Teng, M.F. Bao, X.H. Zhong, L. Ni, X.H. Cai, Phytochemistry 120, 46-52 (2015) 
11. E. Wenkert, D.W. Cochran, H.E. Gottlied, E.W. Hagaman, R. Brazfilho, F.J.D.A. Matos, M.I.L.M. Madruga, Helv. Chim. Acta 59, 2437-2442 (1976)

12. Z.J. Zhan, L.W. Zhang, W.G. Shan, J. Chem. Res. 7, 416-417 (2009)
13. H. Zhang, X.N. Wang, L.P. Lin, J. Ding, J.M. Yue, J. Nat. Prod. 70, 54-59 (2007)

14. B. Albinsson, B. Norden, J. Phys. Chem. 96, 6204-6212 (1992)

15. L. Reed, H. Muench, L.J. Reed, Am. J. Hyg. 27, 493-497 (1938) 